\title{
Cross-sectional Survey of Bovine Fasciolosis in and Around Seyo District of Kelem Wollega Zone, Oromia Region, Western Ethiopia
}

\author{
Kebede B $^{\text {* }}$, lemessa $A^{3}$, Hailu $\mathrm{S}^{2}$, Habtamu $\mathrm{T}^{1}$, \\ Adugna $\mathbf{T}^{3}$ and Getahun $\mathbf{F}^{3}$ \\ ${ }^{1}$ Veterinary Drug and Animal Feed Administration and \\ Control authority, Addis Ababa, Ethiopia \\ ${ }^{2}$ Ministry of Livestock and Fisheries, Addis Ababa, \\ Ethiopia \\ ${ }^{3}$ Seyo District Livestock and Fisheries Office Dembi Dollo, \\ Ethiopia \\ *Corresponding author: Bedaso Kebede, Veterinary \\ Drug and Animal Feed Administration and Control \\ authority, Addis Ababa, Ethiopia
}

Received: January 20, 2017; Accepted: March 03, 2017; Published: March 10, 2017

\begin{abstract}
A cross-sectional study was carried out from May to November, 2016 to determine prevalence bovine fasciolosis in Seyo district, Kelem wollega Zone of Oromia Regional state. A total of $384 \mathrm{fecal}$ samples were randomly collected from local breed cattle and all samples were subjected to standard sedimentation test at Bedelle Regional Veterinary Laboratory Center aimed to detect the presence of Fasciola eggs. The overall prevalence of bovine fasciolosis was 91(23.7\%). Associated risk factors age, sex, body conditions of cattle and PA's were not significantly associated $(p>0.05)$ with the prevalence of bovine fasciolosis. In the study area fasciolosis was a main constraint for the cattle. Therefore, chemotherapeutic measures should be regularly taken to overcome problems induced by fasciolosis.
\end{abstract}

Keywords: Prevalence; Bovine; Fasciolosis; Seyo district

\section{Introduction}

Livestock is an important component of farming system in Ethiopia and that provides a draft power, milk, meat, manure, hides, skin and other products [1]. Currently, livestock population of Ethiopia estimated to be 55.4 million cattle, 26.5 million sheep and 23.78 million goats CSA [2]. However, livestock resources productivity in the country is low due to several constraints among them diseases plays several roles. Fasciolosis is a disease which imposes direct and indirect economic impact on livestock production particularly on the sheep and cattle $[3,4]$. Bovine Fasciolosis is an economically important parasite disease of cattle caused by Genus Fasciola of the two important species Fasciola hepatica and Fasciola gigantica. The distribution of Fasciola hepatica is wide spread in temperate area and tropical high land of Africa, while Fasciola gigantica is wide spread in most parts of tropical Africa [5]. Intermediate host of Fasciola hepatica is Lymnea trancatula which is mud snail that prefers moist temperature condition $\left(15^{\circ} \mathrm{C}-22^{\circ} \mathrm{C}\right)$. Lymnea trancatula is capable of aestivation for at least years in a dry mud [6]. Fasciolosis is a serious problem in highland of Ethiopia where cattle raising are major to local economy [7]. Apart from its veterinary and economic importance, Fasciolosis has recently been shown to be re-emerging and widespread zoonoses affecting people [8]. Seyo district is one of the potential areas in livestock population in the country which is lower in production and productivity due to disease. Among diseases Fasciolosis is the one that locally called 'Bale' [9]. However, no previous studies on the epidemiology of Fasciolosis in cattle were conducted in Seyo district of Oromia regional state. Therefore, the objective of this study was to determine the prevalence of Bovine Fasciolosis in Seyo district Kelem Wollega Zone.

\section{Materials and Methods}

\section{Study area}

The study was conducted from May to November, 2016 in Seyo district of Kelem Wollega Zone southwestern Ethiopia which is $652 \mathrm{~km}$ far from the capital city Addis Ababa. Geographically located at latitude and longitude of $8032^{\circ} \mathrm{N}$ and $34048^{\circ} \mathrm{E}$ respectively. The climate alternate with long summer rain fall (May to September) and winter dry season (October to April) with mean annual rain fall of $750 \mathrm{~mm}-1200 \mathrm{~mm}$. The agro climate condition fall within tropical sub-humid climate and the altitude range from 1705-1850 above sea level with average daily temperature $25^{\circ} \mathrm{C}$ [9]. The vegetation type of the area is characterized by cash crops. The district covers an area of 79,849 hectares and it is bordered by Hawa galan district at east, Anfilo district at west, Gidami district at north and Iluababora zone at south.

\section{Study population}

Study population includes local breeds of cattle managed under traditional management system. There are a total numbers of 80,122 cattle in the Seyo woreda. Among those 384 cattle were randomly selected and examined from Ripha, Gudina, Kure and Karo peasant association (PA's) of Seyo district.

\section{Study design}

The cross-sectional study was designed with the objective to determine the prevalence of bovine Fasciolosis in Seyo district. Body condition for each cattle was determined according to Nicholson and Butterworth [10]. The age of study animals was estimated based on dentition given by De Lahunte and Habel [11] for age determination and information from owners and classified as (1-3 years) young and ( $>3$ years) adult.

\section{Sample size determination and sampling method}

The animals were selected by using simple random sampling method with an expected prevalence of $50 \%$ was taken in to consideration since there was no earlier coprological research work on Fasciolosis in the area. The desired sample size for the study was 
Table 1: Coprological prevalence of bovine Fasciolosis in the district.

\begin{tabular}{|c|c|c|c|c|c|}
\hline PAs & $\begin{array}{c}\text { No of examined } \\
\text { Cattle }\end{array}$ & $\begin{array}{c}\text { No of } \\
\text { Positive }\end{array}$ & Prevalence (\%) & P-Value & $(95 \%) \mathrm{Cl}$ \\
\hline Kure & 97 & 23 & 23.71 & 0.886 & $0.801-1.211$ \\
\hline Gudina & 90 & 22 & 24.44 & & \\
\hline Ripha & 93 & 22 & 23.66 & & \\
\hline Karo & 104 & 24 & 23.08 & & \\
\hline Total & 384 & 91 & 23.7 & & \\
\hline
\end{tabular}

Table 2: Prevalence of bovine Fasciolosis based on age group.

\begin{tabular}{|c|c|c|c|c|c|}
\hline Age & $\begin{array}{c}\text { No of examined } \\
\text { Cattle }\end{array}$ & $\begin{array}{c}\text { No of } \\
\text { Positive }\end{array}$ & Prevalence (\%) & P-Value & $(95 \%) \mathrm{Cl}$ \\
\hline Young & 118 & 28 & 23.73 & 0.999 & $0.843-1.185$ \\
\hline Adult & 266 & 63 & 23.68 & & \\
\hline Total & 384 & 91 & 23.70 & & \\
\hline
\end{tabular}

calculated using 95\% confidence interval and at 5\% absolute precision [12].

\section{$\mathrm{n}=1.96^{2 *} \operatorname{Pexp}(1-\mathrm{Pexp}) / \mathrm{d}^{2}$}

where, $\mathrm{n}=$ required sample size

$\boldsymbol{P} \exp =$ Expected prevalence

\section{$\boldsymbol{d}=$ Absolute precision}

Totally, 384 cattle were randomly sampled in Seyo district to determine the prevalence.

\section{Fecal sample collection and laboratory techniques}

In the laboratory coproscopic examination were performed to detect the presence of Fasciola eggs according to standard technique as described by Hasen and Perry [13]. Fresh fecal samples for parasitological examination were collected directly from the rectum by using disposable plastic gloves and placed in clean screw capped universal bottles. Each sample was labeled with date of submission, age, sex, body condition and place of origin (PA's). Samples were preserved with $10 \%$ formalin solution to avoid the eggs development and hatching for laboratory diagnosis then transported to Bedelle regional laboratory for parasitological examination.

\section{Data management and analysis}

All Data generated from study were entered in to Microsoft Excel data system. The data were thoroughly screened for errors and properly coded before subjecting to statistical analysis. The Data were imported from the Microsoft excel and analyzed using STATA software 11.0 computer to determine the variation in infection prevalence in potential risk factor (Age, Sex, PA's and Body condition). Significances were considered with the "P" value less than 0.05 .

\section{Result}

Out of 384 cattle fecal sample examined an overall prevalence of $91(23.7 \%)$ were found positive for fasciolosis in the study area. The higher prevalence was recorded in Gudina PA's 22(24.44\%) and lower prevalence was in Karo PA's 24(23.08\%). Statistical analysis showed that no prevalence significance $(\mathrm{P}>0.05)$ difference between PA's (Table 1).

Young cattle 28(23.73\%) harbored slightly more infection than
Table 3: Prevalence of Bovine Fasciolosis based on Sex groups.

\begin{tabular}{|c|c|c|c|c|c|}
\hline Sex & $\begin{array}{c}\text { No of examined } \\
\text { Cattle }\end{array}$ & $\begin{array}{c}\text { No of } \\
\text { Positive }\end{array}$ & Prevalence (\%) & P-Value & $(95 \%) \mathrm{Cl}$ \\
\hline Male & 188 & 44 & 23.40 & 0.893 & $0.644-1.654$ \\
\hline Female & 196 & 47 & 23.98 & & \\
\hline Total & 384 & 91 & 23.7 & & \\
\hline
\end{tabular}

Table 4: Prevalence of Bovine Fasciolosis based on body condition.

\begin{tabular}{|c|c|c|c|c|c|}
\hline $\begin{array}{c}\text { Body } \\
\text { condition }\end{array}$ & $\begin{array}{c}\text { No of } \\
\text { examined } \\
\text { Cattle }\end{array}$ & $\begin{array}{c}\text { No of } \\
\text { Positive }\end{array}$ & $\begin{array}{c}\text { Prevalence } \\
(\%)\end{array}$ & P-Value & $(95 \%) \mathrm{Cl}$ \\
\hline Poor & 160 & 38 & 23.75 & 0.987 & $0.617-1.606$ \\
\hline Good & 224 & 53 & 23.66 & & \\
\hline Total & 384 & 91 & 23.7 & & \\
\hline
\end{tabular}

adult cattle and statistical analysis revealed that there is no significant difference $(\mathrm{P}>0.05)$ in prevalence between the age group (Table 2$)$.

Female cattle $47(23.98 \%)$ were harbor slightly more infection than male and statistical analysis showed that no significant $(\mathrm{P}>0.05)$ difference in prevalence between the sex group (Table 3 ).

Poor body condition score cattle $38(23.75 \%)$ were slightly more infected than good body condition cattle and statistical analysis showed that no significant $(\mathrm{P}>0.05)$ difference in prevalence between body condition score (Table 4$)$.

\section{Discussion}

The current study revealed that $91(23.7 \%)$ prevalence were positive for fasciolosis using sedimentation technique as diagnostic method. Studies conducted in different part of Ethiopia indicated that higher prevalence than the current finding 91(23.7\%); 62.2\% in Bahirdar by Fekadu [14], 81.6\% in Ambo Yadeta [15], 56.6\% in Zeway Adem [16], 34\% in Walliso by Rahameto [17], 61.79\% in Gojjam by Yohannis [18].This difference in prevalence of Fasciolosis in Ethiopia may be related with difference in ecological factor available for snail the intermediate host of Fasciola. The occurrence of Fasciolosis in the area is influenced by a multi factorial system which comprises host, parasite and environmental effect. In the natural foci of Fasciolosis the Fasciola and their intermediate and final hosts form an association possessing a potential epidemiological threat [19]. The previous studies that agree with current study were $(22.72 \%)$ at Nekemte by Wasse [20], (24.32\%) in Mekele area by Gebretsadik et al [21].

Infection rate of bovine fasciolosis of the result of the study indicated that the prevalence of poor body condition (23.75\%) and good body condition $(23.66 \%)$ revealed that infection rate has no significant difference $(p>0.05)$ on the prevalence of fasciolosis. The studies agree with current study are study in northern Ethiopia by Rahameto [17] indicates that there is no significance difference association $(\mathrm{P}>0.05)$ between body condition of animals, study in Jimma by Marta [22] indicated that there was no significance difference between age, sex and PA's.

The prevalence of the current study in male and female animals was recorded as $23.40 \%$ and $23.98 \%$ respectively. There was nonsignificant difference $(p>0.05)$ between the two sexes indicating that sex seems no effect on the prevalence of the disease. Similar results have been reported by G graber and Dans [24] and in Arsi by Argew [23].This may be due to the fact that grazing of both sex groups in 
similar pasture. The prevalence of the disease in different PA's of the study areas were very closely similar having Kure (23.71\%), Gudina (24.44\%), Ripha (23.65\%) and Karo (23.08\%) with non-statistical difference $(\mathrm{p}>0.05)$.

In present study, the risk of infection to all age groups were young $28(23.73 \%)$ and adult $63(23.68 \%)$ cattle which is very closed. This could be due to the fact that both young and adult cattle were forced to graze on the same pasture. This finding collaborates with other previous findings of Phiri et al [25].

\section{Conclusion}

The present study revealed that a moderate prevalence of bovine fasciolosis in the study areas and there were no statistical significant difference between risk factors. The higher prevalence of bovine fasciolosis in different PA's was recorded in Gudina which is associated with optimum condition for the intermediate host. Fasciolosis was prevalent in female, young, old and poor body condition cattle. Therefore, the regular chemotherapeutic treatment against fasciolosis and further studies on the epidemiology of Fasciolosis in the study areas are recommended.

\section{References}

1. Funk C, Rowland J, Eilerts G, kebebe E, Biru N, white L, et al. Acclimate trend analysis. Of Ethiopia. Climate change adaptation series. U.S. Geological survey. Ramine early warning system Net-Work informing (FEWSNET). Fact sheet 3053, 6P. 2012.

2. Central statistical authority (CSA). Agriculture sample survey 2010-2011. Report on Livestock and livestock characteristics. Vol.11, statistical Bullet No. 505. Addis Ababa, Ethiopia. 2014

3. Keyyu GD Monrad JKyv, Gaard NC and Kassuku A. Epidemiology of Fasciola gigantica and Amphistomes in cattle on traditional small scale dairy and large scale dairy farm in the southern highlands of Tanzania. 2005; 303-314.

4. Menkier M, Uggla A and Waller P. Prevalence and seasonal incidence of nematode parasites and flukes infections of sheep and goats in eastern Ethiopia. Trop. Anim. Health prod. 2007; 39: 521-531.

5. Urquhart G, Armour J, Duncan J, Dunn A and Jennings F. Veterinary parasitology $2^{\text {nd }}$ ed. Black Well science UK. 1996: 103-113.

6. Miodgra R and LanMcIntyre D. Disease of cattle in the tropics. London. 1996

7. Kifle. Epidemiology of Bovine Fasciolosis in Galma Auraja (Arsi) Ethiopia Veterinary Association proceeding of the $12^{\text {th }}$ conference. Addis Ababa Ethiopia. 1998; 35-42.

8. Esteban J, Gonzalez C, Curtel F, Munoz-Antoli C, Valero M, Bargues M, et al. Hyperendemic Fasciolosis associated with schistosomiasis in villages in the Nile delta of Egypt. Am Jor. Of trop Mediterranean Hyg. 2003; 69: 429-437.

9. Seyo Livestock and Fishery office-2015.
10. Nicholson MJ, Butterworth $\mathrm{MH}$. A guide to body condition scoring of zebu cattle. International Livestock Research Center for Africa, Addis Ababa, Ethiopia.1986

11. DeLahunta A, Habel RE. Teeth, DeLahunta A Habel RE. Applied Veterinary Anatomy. eds In. NP WB Saunders Company. Philadelphia.1986.

12. Thrusfield, M. Veterinary epidemiology second edition university of Edinburgh, black well science. 1995. 180-188.

13. Hanson J and Perry B. The Epidemiology Diagnosis and Control of helminth parasites of ruminants. A Hand book. Food and Agricultural Origination of the United Nations, Rome, Italy. 1994; 72-89.

14. Fekadu R. Ruminant Fasciolosis: study on the clinical occurrence coprology, Morphology and abattoir survey in DebreBirehan and surrounding area M.S.C. thesis. F.V.M. A.A.U. 1988

15. Yadeta B. Epidimology of Bovine and Ovine Fasciolosis and distributions of its snail intermediate host in western showa. PhD thesis, F.V.M, A.A .U, DebreZeit 35. 1994.

16. Adem A. Prevalence of Bovine and Ovine Fasciolosis: A preliminary survey around Ziway town. DVM Thesis, Faculty of Veterinary Medicine Addis Ababa University, Bishoftu, Ethiopia. 1994.

17. Rameto A, Fufa A, Mulgeta B, Solomon M, Bekele $M$ and Alemayew R. Fasciolosis prevalence, Financial losses due to liver condemnation and evaluation of a simple sedimentation diagnostic technique in cattle slaughtered at Hawasa Municipal abattoir, Southern Ethiopia. Ethiopia Vet J. $2010 ; 14: 39-51$

18. Yohanis T. Bovine Fasciolosis, prevalence and economic importance assessment trail on Cattle slaughtered at Bahir Dar manisipal abattoir, D.V.M. thesis, Addis Ababa University, Faculty of Veterinary Medicine DebreZeit, Ethiopia. 1994.

19. Maqbool A, Hayat CS, Alchrar T, Hashmi A. Epidimiology of Fasciolosis in under different managemental condition, Vet.Chiv. 2002; 72: 221-228.

20. Wasse M, Ephrem B, Abdi G. Prevalence and economic loss of bovine Fasciolosis in Dessie municipal abattoir South Wollo zone, Ethiopia. Europe J. Bio.Sci, 1995; 4: 53-59

21. Gebresadik B, kassahun B and Gebrehiwot TP. Revalence and Economic significance of Fasciolosisin cattle in Mekele area of Ethiopia. Trop. Ani. Health and Prod. 2010; 41: 7

22. Marta A. Prevalence of bovine Fasciolosis in selected sub cities of Addis Ababa Dairy farm. D.V.M. Thesis Jimma University. School of Veterinary Medicine. Jimma, Ethiopia. 2008.

23. Grabber M and Dayens P. Molluscs vectors and trematodes Human's and animals in Ethiopia. Revenue d' elavege medicine veterinary days tropicaux. 1974; $27: 307-303$

24. Argaw. Epidimology of Bovine Fasciolosis in Galma Auraja(Arsi)Ethiopia Veterinary Association proceeding of the $12^{\text {th }}$ conference. Addis Ababa, Ethiopia. 1998; 35-42.

25. Phiri AM, Phiri IK, Sisunge CS and Monrad J. Prevalence of fasciolosis in Zambian cattle observed at selected abattoirs with emphasis on age, sex and origin. Journal medicine. 2005; 52: 414-416.
Austin J Vet Sci \& Anim Husb - Volume 4 Issue 1 - 2017 ISSN: 2472-3371 | www.austinpublishinggroup.com Kebede et al. (c) All rights are reserved
Citation: Kebede B, lemessa A, Hailu S, Habtamu T, Adugna T and Getahun F. Cross-sectional Survey of Bovine Fasciolosis in and Around Seyo District of Kelem Wollega Zone, Oromia Region, Western Ethiopia. Austin J Vet Sci \& Anim Husb. 2017; 4(1): 1032. 